\title{
Bridging the Gap for English Language Testing Study in Fiji: Proposing an Evaluation of the Writing Proficiency Level of Pre-first Year and Post-first Year Undergraduate Students
}

\author{
Prashneel Ravisan Goundar \\ Department of Language \& literature, Fiji National University, Lautoka, Fiji
}

\begin{abstract}
Language testing is a complex field of study as there are various factors that need to be taken into account when preparing and assessing the students' language proficiency. However, it plays a pivotal role in society. With the results of language tests used for immigration purposes, university entrance qualifications as well as employment opportunities. Scholars attest that it is obligatory for language teachers to constantly 'assess their students' oral and written performances', and the Common European Framework of Reference for Language (CEFR) offers a variety of oral and writing scales which provide the 'opportunity for a common standard'. This paper argues the significant gaps that are yet to be address in a language testing research and highlights why a study needs to be conducted in Fiji with the university students. The article discusses applying a quantitative methodology thus, a longitudinal research design to conduct a language testing study on writing proficiency levels of undergraduate students; compare the writing proficiency levels of pre-first year and post-first year university students by using academic essay tests of the same cohort; and finally determine undergraduate students' progress (or lack of) in written English over the course of their program.
\end{abstract}

Index Terms - language testing, Fiji, CEFR, language proficiency, applied linguistics, writing

\section{INTRODUCTION}

\section{Language Proficiency in Applied Linguistics}

In the discipline of Applied Linguistics, various fields exist which largely have yet to be explored in the Pacific. One of these fields language testing, can be branched out as language proficiency, which is yet to gain prominence in research in Fiji. This paper discusses the need for a study on written English proficiency of university students in Fiji. Language proficiency is 'the ability of students to use a language in order to make and communicate meaning in spoken and written contexts such as writing an academic paper or addressing a professional audience' (Murray, 2015, p.70). In Fiji, the English language proficiency plays a crucial role as it is essential for everyday living for example, academic performance, university entrance, employment opportunities as well as commerce (Hopf, McDonagh, Wang, \& McLeod, 2018, p.1). However, much of the research that has been conducted on language proficiency in Fiji has yet to attempt a longitudinal study such as that proposed. Deverell (1989) conducted a research at the University of the South that looked at the English proficiency level of foundation year students. The findings provided an implication that 'at least 100 science and 100 social science students lacking proficiency in English' would begin each year with a 'less than fifty percent chance of passing in ten subjects in the foundation program' (Deverell, 1989, p.15). Thus, the paper proposes for the first quantitative evaluation of the undergraduate students' progress (or lack of) in written English over the course of their university program.

Fiji is a 'multilingual, multiracial country' situated in the South Pacific with various languages that make up the nation. Bordering both "the Polynesian and Melanesian parts of the South Pacific, is Fiji with a number of dialects of Fijian" (Geraghty, 1984) and a "multiplicity of Indian languages: Hindi, Gujerati, Punjabi, Urdu, Telegu, Tamil, Malayalam" (Mugler, 1996), and a number of minority languages, the most prominent being Rotuman. In Fiji, since the 1926 Review of Education Commission established "the main language policy-the practice of instruction in the mother tongue in the first three years of primary school and thereafter English replacing the first language; there has not been a major shift in language policy" (Fiji Education Commission, 2000.p.290). The role of 'English increased dramatically as a consequence of a 1916 Education Ordinance policy whereby the government provided financial aid to independent schools on the condition that they taught some English' (Mangubhai, 1984). English is the official language and the language of instruction at primary and secondary levels. However, it is the second language for most people. Students who enroll at university arrive with various levels of proficiency. Hence the relevance of further research.

Further, Cummins (2000, p.202) suggests that 'the controversial issues surrounding bilingual education can only be solved if there is an adequate conceptualization of the nature of language proficiency and of its assessment, specifically relating to academic achievement'. But, for Fiji substantial research in the field of language testing and specially 
language proficiency has yet to explore a quantitative evaluation. This claim was echoed in a language proficiency research in Fiji where the researchers attested that lack of research in language testing or in language proficiency can be attributed to 'the complex linguistic environment, a lack of locally developed testing material, and the limited historical study of Fijian children's language proficiency' (Hopf, McDonagh, Wang, \& McLeod, 2018, p.2).

Therefore, arises a need for a research that will determine the writing proficiency level of undergraduate students in a longitudinal study, whereby the comparison will be made between the pre-first year and post-first year students' writing test. This will give an insight into what are the differences as well as the achievements in writing proficiency of undergraduate students in their one-year university programme. Moreover, the result of the study could be used at a later time to redesign programs in order to provide better support in areas (such as sentence structure, vocabulary usage, mechanics, punctuation, spelling and capitalization) where students performed poorly.

As to writing proficiency, it has fundamentally been assessed by evaluating written segments from language tests', which are interpreted in terms of 'the degree of task fulfilment and evidence of target language control' and according to these criteria, with the results of the test then being evaluated and classified according to the 'expectations of what learners can do at particular levels of language proficiency' (Leclercq, Edmonds, \& Hilton, 2014; Hawkey \& Barker, 2004). Thus, if a study is conducted it will be a landmark study for Fiji as well as the South Pacific as it will be the first quantitative evaluation for writing proficiency for higher education. Finally, it will further contribute to the literature in the field of language testing as an original work in Fiji.

\section{BACKGROUND OF THE STUDY}

This study on writing language proficiency sets out the following parameters on why a research is worth carrying out in Fiji in the field of Applied Linguistics.

Firstly, language proficiency as a quantitative evaluation (longitudinal study) is an unexplored field in Fiji's higher education sector as the earlier studies example Elley \& Mangubhai (1981), Otsuka (2006), Shameem (2002), and Hopf, McDonagh, Wang, \& McLeod (2018) focused only on primary school students and studies such as Elley \& Thompson (1978), Fitzcharles (1984), Chand (2015) and Deverell (1989) are limited cross-sectional design. Therefore, a study will be a new contribution to the existing literature as it is evidently a notable gap. Secondly, in other countries writing proficiency comparison in undergraduate students has not been researched in depth even though they (Singapore, Malaysia, Thailand, Hong Kong, Canada and others) have looked at L1 and L2 based writing topics as will be revealed in the literature review.

To add on, in 2015, the Prime Minister of Fiji, Mr. Frank Bainimarama made comments at a function that 'creating and maintaining the quality of written expression in the English language in Fiji is very important' (Ravulo, 2015). He further added that "far too many people in schools, tertiary institutions, government, and the private sector make basic spelling, grammar and sentence construction errors even those who have got higher degrees from overseas universities', Ravulo (2015) highlights that Bainimarama claimed that in the civil service people either had not learnt or 'had forgotten that words are the tools they use to convey ideas'. However, these statements were based on mere observations, without any primary research data to back up the statements. Therefore, this calls for a research in the written English proficiency levels, which will either support the observations or prove it otherwise.

Finally, the research can be replicated in other multilingual or countries where English is a second language so that the universities there can take precautionary measures in maintaining the appropriate level of written language proficiency level.

\section{LITERATURE REVIEW}

This section will review relevant literature in the field of language testing. It begins by defining proficiency, then provides an overview of the field of language testing before proceeding to highlight relevant research that has been carried out as well as gaps. It concludes by outlining the reasons, why further research in language testing is still needed in Fiji.

\section{A. Defining Proficiency}

Scholars have stated that it is challenging to describe proficiency (Davies 1989, Bialystok \& Sharwood 1985). One of the issues that teachers, researchers, students and language testers encounter is defining 'what it actually means to be proficient in an L2' (Leclercq, Edmonds, \& Hilton, 2014, p.5). Some of the definitions include 'proficiency as the ability to make use of competence' (Taylor, 1988) or 'the extent and adequacy of the learner's control of the language skills in social interaction, acquiring and providing information, and his/her use of them in necessary instrument for nonlinguistic purposes in the border sense' (Oller, 1983). A similar definition was provided by Higgs (1984) who stated that proficiency is "the ability to function effectively in the language in real life contexts" (p.12).

\section{B. An Overview of Language Testing}

The field of language testing can be traced as back as 1,500 years. During the Sui Dynasty (581-618) in China, formal testing began in order to identify individuals who were most suitable within the empire for crucial positions in the administration, without any biasness of their social class (O'Sullivan, 2012, p.9). However, modern English 
language testing only appeared on the scene from the $20^{\text {th }}$ century. In order to test the language performance of persons from the British colonies who wished to pursue education in the UK, the Cambridge Proficiency Examination (CPE) was introduced in 1913. The examination was designed 'on a coherent philosophy of language learning' developed by Henry Sweet (1899) and for this reason Sweet is attributed as the founder of Applied Linguistics (Coombe, Davidson, \& O'Sullivan, 2012, p.11). The developers of CPE prepared the first examination in 1913 using Sweets' method as is depicted in Figure 1 on the guideline of the content of a test.

Part 1

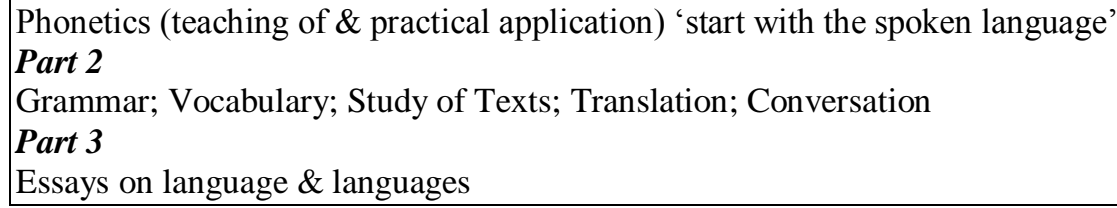

Figure 1 Henry Sweet's Rationally Progressive Method (O'Sullivan, 2012, p.11)

The first CPE in 1913 measured the candidate's language performance that set a precedent for the approach to assessment, which is still dominant in Britain and much of Europe. Figure 2 reveals the content of the first Cambridge Proficiency Examination where similarities can be observed between it and Sweet's (1899) method such as phonetics, translations, and grammar as well as conversation.

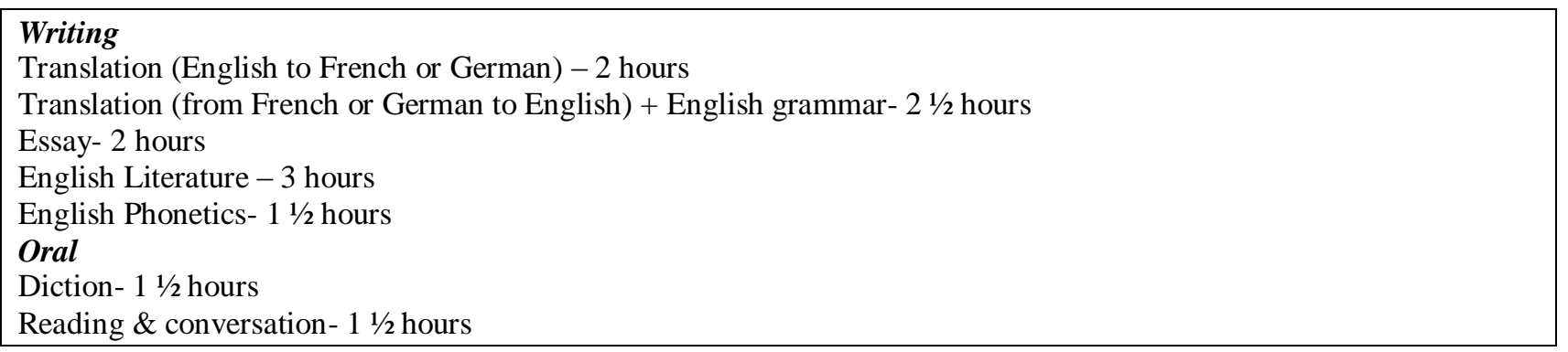

Figure 2 Contents of the 1913 Cambridge Proficiency Examination (O'Sullivan, 2012, p.11)

On the other hand, the United States was interested in standardizing students' written performance. Thorndike (1911, 1912) developed the first standardized examination in 1908 whereby he collected a large sample of students' handwritten essays and asked 200 teachers to organize the scripts in order of legibility. He then created a scale upon which he placed a set of exemplar scripts after which he asked the teachers to compare the samples with the ones on the scale and the closest match would indicate the level. Further, using the same methodology Hillegas in 1912 designed the first standardized scale for written composition and in 1914 Courtis compiled the first standardized examination of English language. Courtis (1914, p.391) explained that 'on the basis of these tests and the requirements of the school it is possible to conclude that an eighth-grade child of standard ability should be able to write an original story at the rate of 18 words per minute and that legibility of the writing should be 60 on the Ayres scale (this measured the relative accuracy of judgments of handwriting), and there should not be more than five mistakes in punctuation per hundred words, two spelling, and two in syntax. In addition, in careful reading the rate should be 230 words per minute, and that in the reproduction of the material, 12 of the original words should be used per minute and that these words should constitute 50 percent of the words used in the reproduction'.

In the early 1960s, another milestone was reached in this field of English language testing, when in the United States the Test of English as a Foreign Language (TOEFL) was implemented. After the introduction of TOEFL, the development of general proficiency examinations continued for another three decades (O'Sullivan, 2012, p.14). 1979 saw the introduction of the Test of English for International Communication (TOEIC) in response to a request from the Japanese Ministry of Trade and Industry for the purpose of testing of language for business contexts. The validity of TOEIC test can be argued upon as the test focuses on general English and result reporting using a norm-referenced reporting system. According to O'Sullivan (2012, p.14), a norm-referenced reporting system 'reports the performance of each individual in terms of the rest of the candidature'.

In the UK, by the early 1980s, the formation of the English Language Testing Service (ELTS) addressed the issue of testing language for specific purposes. Soon, ELTS became the International English Language Testing System (IELTS) which is still prevalent in many countries and used extensively for migration and immigration purposes (O'Sullivan, 2012, p.14). IELTS is considered more of a holistic approach to testing language proficiency which is one of the major reasons why it has become more marketable, similar to the TOEIC.

Finally, by the 1990s the use of IELTS grew from a few thousand candidates per year to over a million. Due to this growth there was a decline of other tests such as the Cambridge ESOL Main Suite in the early years of the $21^{\text {st }}$ century, which implied a shift in emphasis from general to specific purposes testing. As a final point on the overview of language testing, recent years have witnessed the emergence of TOEFL iBT (Internet-based TOEFL) that can be 
classified as 'more acceptable for performance and criterion-referenced test analysis' than the 'traditional classical test statistics' (O'Sullivan, 2012, p.15).

\section{FINDINGS AND DisCUSSIONS}

In Fiji, the latest study that was conducted in the field of language testing was by Hopf, McDonagh, Wang, \& McLeod (2018). It describes the linguistic landscape of Fiji having covered all aspects of those languages which exist in Fiji and how they are being used for communication or 'as a medium of instruction in schools'. The study investigates the 'factors that influence Fijian primary school students' English language proficiency with a total of 150 participants where 75 were students and 75 were caregivers. A quantitative research design was employed (cross sectional). The study revealed that the family's home language had a significant impact on English proficiency and the student academic performance (Hopf, McDonagh, Wang, \& McLeod, 2018, p.11). However, the study did not present proficiency in the other languages spoken by the students.

In language testing research, the 'Common European Framework of Reference for Language' (CEFR; Council of Europe, 2009), has been influential in defining proficiency levels (A1-Breakthrough, A2-Waystage, B1-Threshold, B2Vantage, C1-Effective Operational Proficiency, and C2-Mastery); since its inception in 2001. It is considered a 'useful tool in the development of language test' and has been accepted as the 'most significant recent event on the language education scene in Europe' (Kantarcioglu, \& Papageorgiou, 2012, p.82). The Language Testing journal on language assessment provided significant evidence in its special issue (2005) on how influential CEFR is in the field of language testing. CEFR has been used in numerous language testing studies such as Byram \& Parmenter (2012) of French, Polish, Bulgarian, Argentinian, Chinese, and Taiwanese language; Díez-Bedmar (2012) of the English language, Morrow (2004) of the French language, Little (2005) of the Irish language, Fulcher (2004) of European languages, Alderson, et al. (2006) of the Dutch language, and Hulstijn, Schoonen, De Jong, Steinel \& Florijn (2012) of the Dutch language.

Díez-Bedmar (2012) carried out a study in Spain to investigate the various proficiency levels 'within the same institutional groups' and 'the nature of negative linguistic properties'. This research used the CEFR proficiency levels and a computer-aided error analysis (CEA) to verify the written essays of the English section of the University Entrance Examination. A total of 302 participants were employed in this study and were required to write an essay on the topic 'Where outside Spain would you like to go on a short pleasure trip?' (Callies, Díez-Bedmar, \& Zaytseva, 2014, p.79). The findings of the study revealed that the majority of the secondary school leavers performed at the same B1 proficiency level on the CEFR. The study did not analyze errors at each proficiency level but selected only A2 level that showed students made frequent errors with the use of modal auxiliary verbs. This provides a useful framework for a future study and the CEFR proficiency level will be used in classifying, which level the pre-first year and post-first year undergraduate students stand at in the longitudinal study.

He and Shi (2012) conducted a study in Canada to investigate the writing performances of a group of ESL students on the Language Proficiency Index (LPI). It explored the relationship between topic bias and candidate performance for timed impromptu essays. The paper distinguished between topic based essay testing and timed-impromptu writing tests. This is useful to determine if topical knowledge is required in preparing an English proficiency test. He and Shi point out that "test writers have long striven to devise prompts that avoid cultural or subject-specific bias that might disadvantage certain groups of test takers" (p.444). However, they indicate that fewer studies have investigated whether standardized tests are actually general enough not to require particular cultural or subject-specific knowledge. Furthermore, the relevant studies discussed by He and Shi (2012) reveal that there has been no study conducted on the English proficiency level of undergraduate students. In addition, the studies highlighted by He and Shi (2012) are concerned about field specific writing tests and general topic based. Of worth noting is the six-point analytic rating scale with three components: content, organization, and language (p.449) that was used in this study.

Pappamihiel, Nishimata, and Mihai's (2008) research brings to light how the role of writing has become pivotal in international standard tests such as Test of English as a Foreign Language (TOEFL). The study was conducted in the United States and the participants included second language learners from Korea, Spain, Greece, Thailand, Russia, France and, Japan. These 27 adult English Language Learners (ELLs) enrolled in an intensive English program and the data was gathered during a class where two writing samples were collected with a timed assessment of 30 minutes. Further, this research investigated the issue of whether students benefited from using their L1 when writing in English under timed conditions. Pappamihiel et al (2008) used Cummins's (2000) theoretical framework of Common Underlying Proficiency (CUP) Hypothesis. CUP refers to the 'interdependence of skills and linguistics knowledge' that an L1 learner uses in interpreting the L2 (Cummins, 2000, p.191). This will be helpful in a proposed study as the rubrics designed by Pappamihiel, Nishimata, and Mihai (2008) will be used to assess the essays. The study used McNamara's (2000) score analytic method, which illustrated a clear way of analysing the essays. The findings revealed that the participants who had lower levels of English proficiency scored significantly better when brainstorming in English than when they used their L1 to brainstorm (pp.389-391). The limitations of the study discussed two pivotal points, one that their sample size was small and second that they did not employ one specific L1.

Alfaki (2015) attempted to investigate writing problems encountered by Sudan's university students. The study employed 20 participants where data was gathered through content analysis. After a random selection of students from the age of 18-21 the participants were instructed to write an essay of 150 to 200 words. Thereafter ten English language 
teachers who were selected at random were appointed to examine the 20 samples. The findings revealed various errors such as spelling, errors with tense, vocabulary choice, grammatical errors, uncertainly of modifiers, redundancy, use of transitions, paragraph development and cognitive problems. Even though the study has outline the major areas of concern in writing, the author could have analyzed the findings better. For instance, in the analysis of a sentence Alfaki (2015, p.49) points out to the errors in word choice but does not discuss the error of tenses where the participant has written 'bringed' instead of 'brought'. The sample size is also quite inconclusive; a large number of participants would be able to allow significant amount of data to be collected. Finally, the study has not provided a discussion on the rubrics that was used in the study to assess the students writing skill. This study could have been strengthened if the proficiency levels of the participants were outlined instead of limiting the focus on the writing problems. Alfaki's (2015) study is insightful for a future study as it lists the various categories that need to be highlighted when analyzing the proficiency levels of the undergraduate students in pre-first year and post- first year.

\section{Proposed Methodology}

As this article proposes a study to determine the writing proficiency level of undergraduate students in the field of language testing; it is best to use a test as highlighted in the literature review section. Therefore, two tests (academic essays) should be prepared which will be used in for the pre-first year students' program and then one for the post-first year of their program. There are more than three prominent universities in Fiji where this study can be carried out.

The test will have sociolinguistic questions such as the students name, age, race, gender, and first language on the cover page as the test will be designed specifically for this research. The marking of tests can be done by the researcher and for objectivity all the marked scripts will be given to the researcher's Head of Department and subsequently to the Head of School.

The scores then be recorded using the rubrics provided by Pappamihiel, Nishimata, and Mihai (2008). In determining or comparing the proficiency level of two groups it is crucial to use a method that is able to statistically make this possible and a test provides this mechanism. Rahman (2017) supports this notion, attesting 'a test is something that demonstrates one's competence-incompetence, ability-inability; and that shows an individual's position in the scale consisting of variables such as fail, pass, average, satisfactory, good, and excellent'.

Moreover, a distinct advantage of this method is that an academic test assists in taking a pivotal decision of whether or not a student should be allowed to progress to the next level. Another advantage is that it can compare the performance between students and indicate if a student needs more help or not (Rahman, 2017, p.103) for the remaining two years of their programme. Therefore, using this method will fit in well with the quantitative research design when the data analysis is conducted.

\section{CONCLUSION}

It is timely for a research such as this to be carried out because of the development in testing tools and the experience gained in assessing proficiency since the creation of the CEFR in Europe. After employing a number of qualitative and quantitative methods, the Council of Europe refined more than '2,000 language descriptors used in proficiency scales' globally prior to forming the CERF levels (Kantarcioglu, \& Papageorgiou, 2012, p.85). Due to the nature of the way the descriptors have been 'positively phrased', it has gained popularity as it motivates the learners on what they can do instead of stating what they are not capable of doing. The CEFR has a total of six levels which are:

TABLE 1

COMMON EUROPEAN FRAMEWORK OF REFERENCE FOR LANGUAGE PROFICIENCY LEVELS (ADAPTED FROM ENGLISH PROFILE., 2015)

\begin{tabular}{|l|l|l|}
\hline \multicolumn{2}{|l|}{ Language Proficiency levels } & Descriptors \\
\hline A1: Breakthrough & \multirow{2}{*}{ Basic user } & Can communicate in basic English with help from the listener \\
A2: Waystage & Independent user & Can communicate in English within a limited range of contexts \\
\hline B1: Threshold & & Can communicate essential points and ideas in familiar contexts \\
\hline B2: Vantage & Proficient user & Able to use English fluently and flexibly in a wide range of contexts \\
\hline $\begin{array}{l}\text { C1: Effective } \\
\text { C2: Mastery }\end{array}$ & & $\begin{array}{l}\text { Highly proficient-can use English very fluently, precisely and sensitively in } \\
\text { most contexts }\end{array}$ \\
& & \\
\hline
\end{tabular}

It is pivotal for a new contribution such as the objectives of this research, to be carried out so that it can measure the level of changes and the key components that change in the learners pursuing higher education qualification (undergraduate students). Language tests have largely concentrated on cross sectional studies on the various issues discussed earlier. They have yet to carry out a longitudinal study with the same students from pre-first year to post-first year of the duration of their university term and investigate how much their writing proficiency level has changed over the year. This article provides a clear framework to do precisely that.

Also, paramount stakeholders such as the Fiji Higher Education Commission (FHEC), Ministry of Education, and higher education providers will be interested in the findings of this research in implementing any policy change for all higher education institutions. Finally, the study can be used by other researchers to investigate oral proficiency level of university students or even explore reading proficiency. 


\section{APPENDIX}

\section{A). Sample of the Essay marking Rubrics}

\begin{tabular}{|c|c|}
\hline \multicolumn{2}{|c|}{ Easy Marking Rubrics } \\
\hline \multirow[b]{3}{*}{ Content } & $\begin{array}{l}\text { 30-27: Excellent to very good: Knowledgeable, substantive, thorough development of thesis, relevant to assigned topic } \\
\text { 26-22: Good to average: Some knowledge of subject, adequate range, limited development of thesis, mostly relevant to topic, but } \\
\text { lacks detail }\end{array}$ \\
\hline & 21-17: Fair to poor: Limited knowledge of subject, little substance, inadequate development of topic \\
\hline & 16-13: Very poor: Does not show knowledge of subject, nonsubstantive, not pertinent, or not enough to evaluate \\
\hline \multirow[b]{3}{*}{ Organization } & $\begin{array}{l}\text { 20-18: Excellent to very good: Fluent expression, ideas clearly stated and supported, succinct, well organized, logical sequencing, } \\
\text { cohesive } \\
\begin{array}{l}\text { 17-14: Good to average: Somewhat choppy, loosely organized but main ideas stand out, limited support, logical but incomplete } \\
\text { sequencing }\end{array}\end{array}$ \\
\hline & 13-10: Fair to poor: Nonfluent, ideas confused or disconnected, lacks logical sequencing and development \\
\hline & 9-7: Very poor: Does not communicate, no organization, or not enough to evaluate \\
\hline \multirow[b]{4}{*}{ Vocabulary } & 20-18: Sophisticated: Wide range, effective word or idiom choice and usage, word form mastery, appropriate register \\
\hline & 17-14: Good to average: Adequate range; occasional errors of word or idiom form, choice, usage; but meaning not obscured \\
\hline & 13-10: Fair to poor: Limited range; frequent errors of word or idiom form, choice, usage; meaning confused or obscured \\
\hline & 9-7: Very poor: Essentially translation; little knowledge of English vocabulary, idioms, word forms; or not enough to evaluate \\
\hline Language use & $\begin{array}{l}\text { 25-22: Excellent to very good: Effective complex construction; few errors of agreement, tense, number, word order or function, } \\
\text { articles, pronouns, prepositions } \\
\text { 21-18: Good to average: Effective but simple construction; minor problems in complex constructions; several errors of agreement, } \\
\text { tense, number, word order or function, articles, pronouns, prepositions; but meaning seldom obscured } \\
\begin{array}{l}\text { 17-11: Fair to poor: Major problems in simple and complex constructions; frequent errors of negation, agreement, tense, number, } \\
\text { word order or function, articles, pronouns, prepositions; sentence fragments, run-ons, deletions; meaning confused or obscured }\end{array} \\
\begin{array}{l}\text { 10-5: Very poor: Virtually no mastery of sentence construction rules, dominated by errors, does not communicate, or not enough to } \\
\text { evaluate }\end{array}\end{array}$ \\
\hline \multirow[b]{3}{*}{ Mechanics } & 5: Excellent to very good: Demonstrates mastery of conventions; few errors of spelling, punctuation, capitalization, paragraphing \\
\hline & 4: Good to average: Occasional errors of spelling, punctuation, capitalization, paragraphing but meaning not obscured \\
\hline & $\begin{array}{l}\text { 3: Fair to poor: Frequent errors of spelling, punctuation, capitalization, paragraphing; meaning confused or obscured } \\
\text { 2: Very poor: No mastery of conventions; dominated by errors of spelling, punctuation, capitalization, paragraphing; or not enough to } \\
\text { evaluate }\end{array}$ \\
\hline
\end{tabular}

\section{REFERENCES}

[1] Alderson, J. C., Figueras, N., Kuijper, H., Nold, G., Takala, S., \& Tardieu, C. (2006). Analysing tests of reading and listening in relation to the Common European Framework of Reference: The experience of the Dutch CEFR construct project. Language Assessment Quarterly: An International Journal, 3(1), 3-30.

[2] Alfaki, I.M. (2015). University students' English writing problems: Diagnosis and remedy, International Journal of English Language Teaching, 3 (3), 40-52 Englishes, 10(2), 167-179.

[3] Bialystok, E., \& Sharwood Smith, M. (1985). Interlanguage is not a state of mind: An evaluation of the construct for secondlanguage acquisition. Applied linguistics, 6(2), 101-117.

[4] Byram, M., \& Parmenter, L. (Eds.). (2012). The Common European Framework of Reference: The globalisation of language education policy (Vol. 23). Great Britain, UK: Multilingual matters.

[5] Callies, M., Díez-Bedmar, M. B., \& Zaytseva, E. (2014). Using learner corpora for testing and assessing L2 proficiency. Measuring L2 proficiency: Perspectives from SLA, 78(71), 79-80.

[6] Chand, Z.A. (2015). Language Learning Strategies of Fiji Students and Correlations with Academic Language Proficiency (PhD thesis). The University of the South Pacific, Suva, Fiji. Retrieved from http://digilib.library.usp.ac.fj/gsdl/collect/usplibr1/index/assoc/HASH016a/e2ef6bd9.dir/doc.pdf on 1 December 2019

[7] Coombe, C., Davidson, P., \& O'Sullivan, B. (2012). The Cambridge guide to second language assessment. Cambridge: Cambridge University Press. Pp. 321.

[8] Council of Europe. (2009). Relating Language Examinations to the Common European Framework of Reference for Languages: Learning, teaching, assessment (CEFR): A manual. Strasbourg: Language Policy Division

[9] Courtis, S. A. (1914). Standard tests in English. The Elementary School Teacher, 14(8), 374-392.

[10] Cummins, J. (2000). Language, power, and pedagogy: Bilingual children in the crossfire (Vol. 23). Great Britain, UK: Multilingual matters.

[11] Davies, A. (1989). Communicative competence as language use. Applied Linguistics, 10(2), 157-170.

[12] Deverell, G. (1989). The relationship between English proficiency and academic success at the University of the South Pacific. Directions, 11(1), 10-18. 
[13] Díez-Bedmar, M. B. (2012). The use of the common European framework of reference for languages to evaluate compositions in the English exam section of the university admission examination. Revista de Educación, 357, 55-79.

[14] Elley, W. B., \& Mangubhai, F. (1981). The impact of a book flood in Fiji primary schools. New Zealand Council for Educational Research.

[15] Elley, W.B. and Thompson, J. (1978.) The English Language Skills of USP Foundation Students. Mimeo, IOE, USP, Suva.

[16] EnglishProfile. (2015). Why is the CEFR useful for teachers and leaners? Retrieved from https://www.englishprofile.org/thecefr/cefr-for-teachers-learners? on 1 December 2019.

[17] Fiji Islands Education Commission/Panel. (2000). Learning to LiveTogether: Directions for Education in the Fiji Islands Report. Suva. Government of Fiji. Ministry of Education.

[18] Fitzcharles, K. (1984). Report on Progressive [Proficiency in] English Measure: Semester I Results - August 1984. Mimeo, English Discipline, USP, Suva.

[19] Fulcher, G. (2004). Deluded by artifices? The common European framework and harmonization. Language Assessment Quarterly: An International Journal, 1(4), 253-266.

[20] Geraghty, P. (1984). Language policy in Fiji and Rotuma. Duivosavosa: Fiji's Languages-their use and their future. Fiji Museum Bulletin, 8, pp.32-84.

[21] He, L., \& Shi, L. (2012). Topical knowledge and ESL writing. Language Testing, 29(3), 443-464. doi: http://dx.doi.org/10.1177/0265532212436659.

[22] Higgs, T.V. (ed.). (1984). Teaching for Proficiency, the Organizing Principle. ACTFL Foreign Language Education Series. Lincolnwood, Ill.: National Textbook, Canadian Modern Language Review, 42(5), pp. 1026-1027.

[23] Hopf, S. C., McDonagh, S. H., Wang, C., \& McLeod, S. (2019). English language and literacy proficiency of students in an urban Fiji primary school. Language, Culture and Curriculum, 32(2), 223-238.

[24] Hulstijn, J. H., Schoonen, R., De Jong, N. H., Steinel, M. P., \& Florijn, A. (2012). Linguistic competences of learners of Dutch as a second language at the B1 and B2 levels of speaking proficiency of the Common European Framework of Reference for Languages (CEFR). Language Testing, 29(2), 203-221.

[25] Kantarcioglu, E., \& Papageorgiou, S. (2012). The Common European Framework of Reference. The Cambridge Guide to Seconcl Language Assessment.

[26] Leclercq, P., Edmonds, A., \& Hilton, H. (Eds.). (2014). Measuring L2 proficiency: Perspectives from SLA (Vol. 78). Great Britain, UK: Multilingual matters.

[27] Little, D. (2005). The Common European Framework and the European Language Portfolio: Involving learners and their judgements in the assessment process. Language testing, 22(3), 321-336.

[28] McNamara, T. (2000). Language testing. Oxford, UK: Oxford University Press.

[29] Morrow, K. (Ed.). (2004). Insights from the common European framework. Oxford, UK: Oxford University Press.

[30] Mugler, F., \& Lynch, J. (1996). Language and education in the Pacific. In F. Mugler \& J. Lynch (Eds.), Pacific languages in education (pp. 1-9). Suva: Institute of Pacific Studies, The University of South Pacific.

[31] Murray, N. (2015). Seeking definitional clarity: What is 'English language proficiency'? In Standards of English in Higher Education: Issues, Challenges and Strategies (pp. 69-98). Cambridge: Cambridge University Press. doi:10.1017/CBO9781139507189.004.

[32] O'Sullivan, B. (2012). A brief history of language testing. The Cambridge guide to second language assessment, 9-19.

[33] Oller Jr, J. W. (1983). Issues in language testing research. Newbury House Publishers, Inc., Rowley, MA 01969.

[34] Otsuka, S. (2006). Cultural influences on academic performance in Fiji: a case study in the Nadroga/Navosa province (PhD thesis). The University of Sydney, Sydney, Australia. Retrieved from https://ses.library.usyd.edu.au/handle/2123/1416 on 4 March 2020.

[35] Pappamihiel, N. E., Nishimata, T., \& Mihai, F. (2008). Timed Writing and Adult English - Language Learners: An Investigation of First Language Use in Invention Strategies. Journal of Adolescent \& Adult Literacy, 51(5), 386-394.

[36] Rahman, M. S. (2017). The Advantages and Disadvantages of Using Qualitative and Quantitative Approaches and Methods in Language' Testing and Assessment' Research: A Literature Review. Journal of Education and Learning, 6(1), 102-112.

[37] Ravulo, A. (2015). PM stresses use of proper English at FNU awards. Fijivillage.com. Retrieved from http://fijivillage.com/news/PM-stresses-use-of-proper-English-at-FNU-awards-25sr9k/ on 1 December 2019.

[38] Shameem, N. (2002). Multilingual proficiency in Fiji primary schools. Journal of Multilingual and Multicultural Development, 23(5), 388-407.

[39] Sweet, H. (1899). 1964. The Practical Study of Languages. A Guide for Teachers and Learners. Oxford, UK: Oxford University Press.

[40] Taylor, D. S. (1988). The meaning and use of the term 'competence' in linguistics and applied linguistics. Applied linguistics, 9(2), 148-168.

[41] Thorndike, E. L. (1911). A scale for measuring the merit of English writing. Science, 33(859), 935-938.

[42] Thorndike, E. L. (1912). The measurement of educational products. The School Review, 20(5), 289-299.

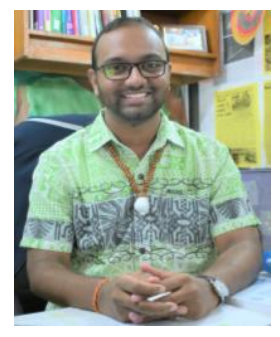

Prashneel R. Goundar is a Lecturer in Linguistics at the School of Communication, Language \& Literature, The Fiji National University, Fiji. He teaches Academic English as well as linguistics courses to both pre-service and in-service undergraduate students. Prior to his role at FNU, Goundar was the Deputy Director and English Language Teacher for a reputable UK organization based in Nadi, Fiji where he was instrumental in setting up and managing the English language programs. His Master of Arts Degree in Teaching English as a Second Language investigated vocabulary learning strategies (VLSs) employed by EFL students that has been published in the Quartile 2 ranked journal, English Language Teaching. He recently graduated with a Postgraduate Certificate in Tertiary Teaching from The University of the South Pacific. His publications include research papers in ranked journals, books, book chapters, critical essays, newspaper 
articles, book reviews and others in Fiji, Australia, Canada, Tunisia, Croatia, India, and the United Kingdom with Cambridge University Press. Goundar is a Member of the Editorial Board of English Language Teaching and Higher Education Studies (Canadian Center of Science and Education), Journal of Applied Research in Higher Education (Emerald Group Publishing Ltd, United Kingdom), and is also the Chief Education Editor for Positively Transforming World (PTW) based in Melbourne, Australia. Originally from Nadi, Goundar attended Shri A. D. Patel Memorial Primary School before completing his high school education at Swami Vivekananda College. Email him: prashneel.goundar@fnu.ac.fj or follow him on Instagram: @prgoundar Twitter: @ prgoundar 